\author{
Wanda Stec \\ iD https://orcid.org/0000-0003-2530-2489 \\ Uniwersytet Gdański \\ Wydział Filologiczny \\ Instytut Rusycystyki i Studiów Wschodnich \\ Zakład Języka Rosyjskiego i Przekładoznawstwa \\ 80-308 Gdańsk, ul. Wita Stwosza 51 \\ wanda.stec@ug.edu.pl \\ https://doi.org/10.18778/8220-520-6.07
}

\title{
POSTRZEGANIE TRUJĄCYCH ROŚLIN LECZNICZYCH PRZEZ PRYZMAT ICH NAZW (NA PRZYKŁADZIE NAZEWNICTWA POLSKIEGO I ROSYJSKIEGO)
}

\section{Perception of poisonous medicinal plants based on their names (as exemplified by the Polish and Russian nomenclature)}

\section{Восприятие ядовитых мекарственных растений сквозь призму их наименований (на примере номенклатуры на польском и русском языках)}

\begin{abstract}
Streszczenie
Nazwy botaniczne są odbiciem tego, jak ludzie odbierają, interpretują i kategoryzują w języku część otaczającej ich rzeczywistości, jaką stanowi świat roślin. Celem artykułu jest pokazanie, w jaki sposób w mianownictwie kształtuje się obraz roślin, które są trujące, a jednocześnie stosowane w leczeniu. Autorka analizuje motywy nazewnicze na wybranych przykładach nazw zwyczajowych oraz ludowych w języku polskim i rosyjskim, na tle mającej międzynarodowy zasięg łacińskiej nomenklatury botanicznej. $\mathrm{W}$ procesie nominacji językowej trujących roślin leczniczych uwzględniane są kryteria, mające charakter zarówno obiektywny, bazujący na wiedzy, obserwacji, doświadczeniu, jak i subiektywny, u którego podstaw leży ocena i skojarzenia. Nazwy nie zawsze zawierają przekaz nt. szkodliwego działania, ponieważ w trakcie ich nadawania mogły dominować inne właściwości.
\end{abstract}




\section{Summary}

Botanical names reflect how people perceive, interpret, and categorize the world of plants from the linguistic point of view. The article aims to demonstrate how the image of plants that are poisonous and, at the same time, used in medicinal treatment is shaped by their denomination. The author analyzes the motivations for nomenclature on the examples of common and folk names in Polish and Russian, against the background of the international Latin botanical nomenclature. In the process of linguistic nomination of poisonous medicinal plants, the criteria which are taken into account are both objective, based on knowledge, observation, and experience, as well as subjective, based on evaluation and associations. The names do not always reflect the plants' harmful impact on people because their remaining properties might have prevailed during the linguistic nomination process.

\section{Резюме}

Ботанические названия представмяют собой отражение того, как мюАи воспринимают, истолковывают и систематизируют в языке такую часть окружающей Аействительности, как растительный мир. Цель статьи - показать, каким образом в именовании формируется образ растений, которые одновременно и ядовиты, и применяются в мечении. Автор анахизирует принципы номинации на избранных примерах ботанических и народных названий на польском и русском языках, на фоне международной матинской ботанической номенклатуры. В процессе языковой номинации ядовитых мекарственных растений принимаются во внимание критерии как объективные, основанные на знаниях, наблюдении, опыте, так и субъективные, базирующиеся на оценке и ассоциациях. Названия не всегда передают информацию о вреАном возАействии, Потому что во время их присвоения могли преобладать Аругие свойства.

Słowa kluczowe: trujące rośliny lecznicze, nazwy roślin, nominacja językowa.

Keywords: poisonous medicinal plants, plant names, linguistic nomination.

Кмючевые слова: ядовитые мекарственные растения, наименования растений, языковая номинация.

Wybitny polski językoznawca Witold Doroszewski w swoich rozważaniach napisał, że "Język jest nie tylko zwierciadłem, w którym odbija się świat, ale i pryzmatem, przez który obrazy świata załamują się w szczególny sposób” (Doroszewski, 1982, 131). Takim swoistym pryzmatem pozwalającym interpretować otaczającą rzeczywistość są nazwy nadawane roślinom. Miana te są bardzo charakterystyczne, bowiem nie tylko oznaczają, umożliwiając identyfikację poszczególnych gatunków, ale niosą w sobie informacje i wskazówki dotyczące samych roślin, a także możliwości ich stosowania. W nazewnictwie mogą być utrwalone różne właściwości organizmów roślinnych (realne i przypisywane), sposoby ich 
wykorzystywania, konotacje z nimi związane - wszystko, co wpływa na to, jak nazywane rośliny są odbierane przez człowieka. Poprzez akt nominacji językowej ten zgoła niemały i jakże ważny wycinek świata zewnętrznego staje się bardziej dostępny, zrozumiały, bliższy ludzkiemu poznaniu. Obserwując gwałtowne pogorszenie się stanu środowiska naturalnego w ostatnich dziesięcioleciach, warto podkreślić, że to właśnie rośliny warunkują życie na Ziemi, wytwarzając tlen $\mathrm{w}$ procesie fotosyntezy, od zarania dziejów będąc nieodłącznym towarzyszem człowieka i służąc mu jako pożywienie, lekarstwo, budulec. Bogate i różnorodne mianownictwo roślinne stanowi interesujący przedmiot badań dla językoznawcy, szczególnie w aspekcie porównawczym.

Wyjątkowo użyteczną grupą roślin, dość zróżnicowaną pod względem systematycznym, są gatunki lecznicze, wykorzystywane w terapii i profilaktyce schorzeń, dostarczające „surowców zawierających w swoim składzie określone substancje chemiczne mające wpływ na prawidłowy przebieg metabolizmu w organizmie człowieka” (Szempliński, 2017, 18). Według definicji Światowej Organizacji Zdrowia za roślinę leczniczą uznawana jest każda roślina, która podawana człowiekowi lub zwierzęciu w jakiejkolwiek postaci wywiera uchwytne działanie fizjologiczne (Olesińska, Sugier, Luchowska, 2016, 17). Należy mieć na uwadze, że działanie to może być pozytywne lub negatywne i zależy przede wszystkim od zastosowanej dawki, co oznacza, że roślina lecznicza użyta niewłaściwie bądź w nadmiarze staje się środkiem szkodliwym, a nawet trującym. Zauważył to już w XVI w. słynny szwajcarski lekarz Paracelsus ${ }^{1}$, będący twórcą pewnego aforyzmu, który trwale zapisał się w historii medycyny: Dosis facit venenum - „Dawka czyni truciznę" (Dzieje medycyny w Polsce, 2016, 62). Sentencja ta wskazuje na podstawową i aktualną do dziś zasadę stosowania leków ziołowych, opierającą się na ustaleniu, a następnie przestrzeganiu odpowiedniej dawki.

Trujące właściwości roślin wynikają z faktu, że wytwarzają i kumulują one w swoich organach związki chemiczne mające charakter wtórnych metabolitów, które najprawdopodobniej służą im do obrony przed chorobotwórczymi bakteriami, grzybami czy wirusami, a także przed zjadaniem przez zwierzęta roślinożerne

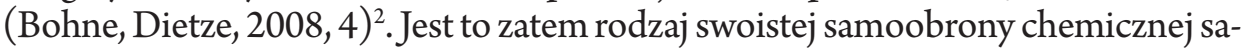

${ }^{1}$ Phillippus Aureolus Theophrastus Bombastus von Hohenheim, znany jako Paracelsus (1493-1541).

${ }^{2}$ Do substancji biologicznie czynnych $\mathrm{w}$ trujących roślinach leczniczych należą przede wszystkim alkaloidy i glikozydy, ale także saponiny, kumaryny, terpenoidy, niektóre kwasy organiczne, olejki eteryczne. Toksyczność zależy od warunków klimatycznych, glebowych, od wieku i fazy rozwoju rośliny, podlega wahaniom dobowym, rocznym (okres wegetacji), cechuje się różnym stopniem trwałości, a przy tym zawartość substancji szkodliwych jest nierównomierna w poszczególnych organach roślinnych (Mowszowicz, 1982, 8-9). Związki toksyczne i rakotwórcze zawarte w roślinach mogą wnikać do organizmu przez układ pokarmowy, oddechowy i przez skórę. 
mych roślin, która jednak może doprowadzić do zatrucia, a nawet śmierci zwierząt lub człowieka, przy czym „понятие ядовитости растений весьма относительно, поскольку многие из них ${ }^{3}$ используют Аля получения мекарственного сырья"4 (Сельскохозяйственный энииклопедический словарь, 1989, 618). Dlatego też wiedza o toksyczności roślin jest nieoceniona, szczególnie zaś gatunków najbardziej rozpowszechnionych, rosnących dziko, spotykanych w lasach, parkach i na łąkach.

W nazewnictwie botanicznym utrwalana jest wiedza kolejnych pokoleń, dotycząca różnych cech roślin - zarówno użytecznych, jak i szkodliwych. W niniejszym artykule zostaną poddane analizie i omówieniu wybrane nazwy trujących roślin leczniczych w języku polskim i rosyjskim - w celu prezentacji sposobu postrzegania tego specyficznego wycinka świata roślinnego przez użytkowników dwóch języków słowiańskich. Motywy nazewnicze wskazujące na toksyczność i szkodliwość gatunków będą pokazane na przykładach polskich i rosyjskich nazw zwyczajowych oraz ludowych, na tle mającej międzynarodowy zasięg łacińskiej nomenklatury botanicznej ${ }^{5}$. Należy podkreślić, że nie są to jedyne motywacje $\mathrm{w}$ nazewnictwie trujących roślin leczniczych, bowiem $\mathrm{w}$ ich nominacji językowej mogą być uwzględniane także inne kryteria ${ }^{6}$.

3 растений - dodano WS.

4 Przykładowo, preparaty uzyskane z roślin o właściwościach odurzających, użyte pod kontrolą lekarza mogą być stosowane w celach leczniczych, jak chociażby do uśmierzenia bólu czy celowego uśpienia chorego. Większość gatunków uważanych za trujące dla roślin i zwierząt to jednocześnie rośliny wykorzystywane w medycynie - tradycyjnej (ludowej) lub oficynalnej. Część z nich wchodzi w skład surowców farmakopealnych.

5 Omawiane nazwy botaniczne w języku polskim i rosyjskim zostały wyekscerpowane ze specjalistycznych pozycji z zakresu botaniki, zielarstwa i ziołolecznictwa ujętych w przypisach i bibliografii. Przy zestawianiu łacińskich nazw roślin leczniczych z ich odpowiednikami nomenklaturowymi w językach narodowych korzystałam z: Mirek et al. (2002); Gawryś (2008); Mowszowicz (1982); Болотина (2007), a także z informacji dostępnych na stronach internetowych projektów naukowych poświęconych taksonomii i systematyce botanicznej: (Плантариyм; Atlas roślin naczyniowych Polski). Jako źródło badanych nazw ludowych (gwarowych, regionalnych, dialektalnych, a także nazw dawnych) posłużyły prace językoznawców polskich i rosyjskich, ujęte w przypisach i bibliografii, poradniki zielarskie, przewodniki botaniczne, a także słowniki nazw. Przykłady polskich i rosyjskich nazw trujących roślin leczniczych, w których strukturze występują elementy w różny sposób informujące o toksyczności, wyróżniono w tekście drukiem pochyłym (kursywą). W celu właściwej identyfikacji gatunków do poszczególnych nazw w językach narodowych przyporządkowano łacińskie nazwy naukowe, które także zapisano kursywą, stosownie do zaleceń Międzynarodowego Kodeksu Nomenklatury Botanicznej, przy czym niezależnie od tego, czy zawierają elementy wskazujące na to, iż oznaczana roślina jest trująca, czy też nie.

${ }^{6}$ Nie jest to jednak tematem artykułu, dlatego w niniejszym tekście ograniczono się jedynie do wybranych nazw (spośród wielu istniejących), odnoszących się do trujących właściwości gatunków. 
Nazwy trujących roślin leczniczych mogą zawierać w sobie obiektywne informacje o ich toksycznych właściwościach, wynikające z wiedzy, obserwacji, doświadczenia w stosowaniu. Taki model nominacyjny ma znaczenie praktyczne, bowiem niejako ostrzega użytkowników języka przed przypadkowym spożyciem rośliny ${ }^{7}$, które może skutkować zatruciem bądź nawet śmiercią.

Niektóre z tego typu nazw mogą obrazować konkretne problemy zdrowotne wynikające z ewentualnego spożycia rośliny, tym samym wskazując na potencjalne objawy zatrucia. Tego rodzaju modele nominacyjne występują w nazwach znanych i stosowanych od czasów antycznych roślin halucynogennych $\mathrm{z}$ rodzaju psiankowatych (Solanaceae), takich jak lulek czarny, ros. белена чёрнал (Hyoscyamus niger L.), nazywany lulkiem jadowitym, szalejem czarnym, blekotem czarnym. Rosyjska nazwa rodzajowa белена wywodzi się z prasłow. ${ }^{*} 6 \mathrm{e}_{\mathrm{H}} \mathrm{\textrm {b }},{ }^{*} 6 \mathrm{e} \Lambda \mathrm{нь}$, oznaczającego „бреА, бессвязная речь, видения, грезы” (zob.: Шапошников, 2010, 56). Jeszcze bardziej obrazowe są rosyjskie ludowe określenia lulka, takie jak: бешеная трава, бешеница, бесиво, дурь-трава, одурь, блекота, немица. Wiele 'mówiące' miana: сонная одурь, сон-трава, сонная вишня, бешеная ягода, бешенииа, безумнал ягода, вишня бешеная odnoszą się do pobudzającego ośrodkowy układ nerwowy pokrzyku wilczej jagody, ros. красавка бемладонна (Atropa belladonna L.). Wyjątkowo symptomatyczne są rosyjskie nazwy innej rośliny narkotycznej z tego rodzaju, zawierającej trujące alkaloidy - bielunia dziędzierzawy (Datura stramonium L.), przy czym zarówno nazwa botaniczna дурман обыкновенный, jak gwarowe określenia typu: одурь-трава, шальнал трава, шалёнка, дурнопьян (дуропьян), дурнишник, дурье зелье, бешеное зелье, бешеные (пьянысе) огуриы, болиголов, собачья бесила wskazują na silne działanie odurzające i towarzyszące mu objawy zatrucia występujące po spożyciu rośliny. Polskie ludowe nazwy bielunia informujące o zgubnych następstwach eksperymentowania $\mathrm{z}$ tą niebezpieczną rośliną ${ }^{8}$ to m.in. blekot i bieluń jadowity. Na bóle i zawroty głowy wywołane wdychaniem olejku eterycznego wydzielanego przez bagno zwyczajne, ros. багульник болотный (Ledum palustre L.) wskazują jego ludowe miana rosyjskie: болиголов, болотньй болиголов, головолом, гоноболь, болотная одурь, дурман болотный, дурман-трава, пьяная трава (Аагерь 2002, 41). W polskich gwarowych nazwach rośliny takich informacji brak, odznaczają się one inną motywacją semantyczną. Trujący i leczniczy zarazem kopytnik pospolity, ros. копытень европейский (Asarum europaeum L.), ze względu na właściwości wykrztuśne podobne do działania ipekakuany prawdziwej, ros. рвотный

7 Także przed: wdychaniem oparów rośliny, dotknięciem rośliny - w wypadku, jeśli do zatrucia może dojść w sposób inny niż drogą pokarmową.

${ }^{8}$ Już prawie 30 lat temu B. Kuźnicka pisała: „Znane są powszechnie używane 'kompoty' z maku, ale także - odurzanie się nasionami bielunia dziędzierzawy, który potocznie nazywany jest 'haszyszem Targówka”' (Kuźnicka, 1992, 112). 
корень (Carapichea ipecacuanha (Brot.) L. Andersson) i związane z tym objawy zatrucia w postaci silnych wymiotów, bywa nazywany 'polska ipekakuana' i 'polska wymiotnicaq ${ }^{9}$. Niektóre z rosyjskich ludowych mian kopytnika, w szczególności, takie jak: рвотный корень, блевунья, блякотник, плющ поземный, чилибуха, w obrazowy sposób odzwierciedlają symptomy zatrucia rośliną (Хапаев, Хапаева $2015,30,32,176,200)$.

Nominacja językowa trujących roślin leczniczych może mieć charakter subiektywny, u którego podstaw leży pejoratywna ocena i skojarzenia. Wówczas ich metaforyczne nazwy niosą przekaz apotropaiczny, kojarzą się z diabłem, czarami, zmarłymi i in., cechując się negatywnym wartościowaniem. Jako przykład mogą posłużyć polskie gwarowe określenia bielunia dziędzierzawy - czarcie (diabelskie, cygańskie, czarowne) ziele, ziele czarownic, roślina diabta (zob.: Stec, 2011, 163-167), lulka czarnego - trupie ziele, widłaka goździstego - czarcia drabina. Wspomniane już bagno zwyczajne to w polskich gwarach m.in. czarcie żebro, w rosyjskich zaś - вампирий коренъ. Trujący kąkol polny, ros. куколь обыкновенный (Agrostemma githago L.) nazywany jest diabelskimi kwiatami i roślina diabelska (Waniakowa, 2012, 109), a nawet siedziba diabła (Szcześniak, 2008, 197-198). Bez czarny, ros. бузина чёрная (Sambucus nigra L.) w języku rosyjskim ma nazwy gwarowe бес-дерево і око дьявола. Znamienne są rosyjskie ludowe miana wawrzynka wilczego lyka (Daphne mezereum L.) - чертов корень, чертов обгрызок, чертогрыз, чертова борода (Аавренова, Аавренов, 1997, 165-166).

W strukturze części nazw trujących roślin leczniczych mogą być przymiotniki pochodzące od nazw zwierząt drapieżnych, tradycyjnie uważanych przez ludzi za groźne, przede wszystkim 'wilczy'/'волчий, niekiedy również 'psi'/'собачий. Są to nazwy metaforyczne, w których podstawą przeniesienia znaczenia nie jest zewnętrzne podobieństwo między rośliną a zwierzęciem, tylko skojarzenie tej rośliny $\mathrm{z}$ drapieżnikiem stanowiącym dla człowieka potencjalne niebezpieczeństwo, zatem podobieństwo wynika $\mathrm{z}$ analogii do poczucia zagrożenia (Stec, 2016, 109-110). Obecność takiego składnika w nazwie to swoiste językowe ostrzeżenie przed spożyciem rośliny tak nazwanej, za pomocą epitetu 'odzwierzęcego' mogą być wskazywane najbardziej trujące organy roślinne. Ta kategoria pojęciowa występuje nie tylko w ekspresywnym i oceniającym mianownictwie ludowym, ale również w nazwach botanicznych w językach narodowych, które zazwyczaj nie są nacechowane stylistycznie. Przykładem może być silnie trujący pokrzyk wilcza jagoda, którego polskie ludowe miana brzmią: wilcza jagoda, wilczojagoda, wilcza wiśnia, psia wiśnia, psinki (Bobrowicz, online). Bardzo wymowne są także inne ludowe określenia tej rośliny, w tym rosyjskie - вишня

9 Nie są to jednak nazwy ludowe (te są motywowane wyglądem liści), tylko popularne określenia rośliny stosowane w reklamie i handlu. 
песья, волчьи ягоды оraz polskie - krzykawiec, wisielec, które podobnie jak człon rodzajowy nazwy botanicznej pokrzyk nawiązują do legendy mandragory,

której korzeń o kształcie przypominającym postać ludzką wydawał krzyk podczas wyrywania. [...] Druga część nazwy - wilcza jagoda związana jest z wykorzystywaniem tej rośliny jako trucizny na wilki. Do dołów-pułapek podrzucano mięso zatrute sokiem z owoców pokrzyku (Leksykon roślin leczniczych, 1990, 385; Kopaliński, $1985,646-647,899)$.

Trujący krzew wawrzynek wilczetyko, ros. волчеягодник обыкновенный ${ }^{10}$, w gwarach ma określenia równie sugestywne: волчье ^ыюко, волчья ягода (волчьи ягоды), волчеягодник, волчник, волчий переи, волчий плющ. Kokoryczka wonna, czyli купена аптечная (Polygonatum odoratum (Mill) Druce.), której trujące owoce mogą być mylone $\mathrm{z}$ owocami borówki czernicy, znana jest pod nazwami волчьи ягодьи, волчьи глазки, волчья трава, ale takżе воронеи, вороньи глаза. Polskie nazwy ludowe kokoryczki nie mają jednak 'wilczej' motywacji i nie informują o możliwym zagrożeniu, podobnie jak polskie nazwy kruszyny pospolitej, ros. крушина момкая (Frangula alnus Mill.), w odróżnieniu od mian rosyjskich typu: волчве (песье) дерево, волчьи (вороньи, сорочьи) ягоды (Аагерь, 2002, 117). Halina Chodurska $(2003,340)$, odnosząc się do pochodzącego od nazwy wilka miana воячья / волчья трава (борец волчий, czyli tojad lisi, Aconitum lycoctonum L. em. Koelle.), które można rozpatrywać jako kalkę nazwy niemieckiej, czeskiej lub polskiej, zwraca uwagę na fakt, iż „niekiedy tożsame określenia ziół bywają rezultatem podobnego sposobu tłumaczenia odmiennych fitonimów obcej proweniencji na języki wschodniosłowiańskie" ${ }^{11}$. W. Kołosowa pisze, że pośród ludowych mian tojadu

[...] Аовольно большая группа явмяется отзоонимными образованиями от корня волк-, встречающимися практически у всех славян. Это можно объяснить как ссылкой на реально существовавшие охотничьи практики, так и широко распространенной семантической моделью 'волк' $\rightarrow$ 'ядовитое растение' (Комосова, 2011, 70).

Dla zilustrowania powyższego stwierdzenia Kołosowa przytacza przykłady nazw w różnych językach słowiańskich odnoszące się do gatunków należących do rodzaju tojad i zawierające 'wilczy' komponent, w tym rosyjskie: волкобойник, волкогуб, волкана, волкобой, волхунога і polskie: wilko mord, wilczy

10 Nazwy synonimiczne: волчеягодник смертельный, волчник обыкновенный.

11 Autorka ma na uwadze nazwy ludowe rośliny w tych językach, które, jak pisze: „zapewne powielają modele średniowiecznej nomenklatury łacińskiej” (zob. Chodurska, 2003, 147-148). 
mord (ibidem). Oprócz przymiotnika wilczy / волчuй w niektórych z rosyjskich mian ludowych występuje także synonimiczny regionalizm бupючuŭ, pochodząсу od wyrazu бирюк, сzyli волк-одиночка (Ожегов online). Jako przykład można podać nazwę бирючьи ягоды, którą określana jest silnie trująca psianka słodkogórz, czyli пасмен сладко-горький (Solanum dulcamara L.), сzу бирючина - nazwę przypisaną do trzmieliny zwyczajnej, ros. берескмет европейский (Еuonymus europaea L.) i szakłaka pospolitego, ros. жостер слабительный (Rhamnus cathartica L.) (Шутов, 2016).

W nazwie może być ujęte łudzące podobieństwo rośliny trującej do innej rośliny - jadalnej (podobieństwo poszczególnych organów - liści, korzeni, bulw, owoców, nasion), a przed przypadkowym spożyciem może ostrzegać przymiotnik 'psi' / 'собачий' i pochodne od wyrazu 'pies' / 'собака'. Przypominający pietruszkę zwyczajną (liście) śmiertelnie trujący blekot pospolity (Aethusa cynapium L.) w gwarach polskich określany jest jako psia pietruszka i pietrasznik, w rosyjskich podobnie - собачья петрушка, собашница петрушечнал. Mylenie tych dwóch gatunków jest przyczyną zatruć u ludzi, tym bardziej, że blekot jest dość pospolitym chwastem ogrodowym. Psia pietruszką i pietrasznikiem plamistym nazywany jest także niezwykle niebezpieczny szczwól plamisty (Conium maculatum L.). Zwierzęta jednak nie ulegają zbyt częstym zatruciom zarówno blekotem, jak i szczwołem, ponieważ obydwie rośliny wydzielają silną woń (Mowszowicz, 1972, 110, 112). Szczególnie cuchnący jest szczwól, który po roztarciu oraz gdy więdnie ma odrażający zapach mysiego moczu, przypominający zapach padli$n y^{12}$. To, że rośliny trujące odznaczają się przykrym zapachem, stanowi podpowiedź dla zwierząt, aby nie spożywały toksycznego dla nich pokarmu roślinnego. Informacje o nieprzyjemnym zapachu roślin trujących mogą zawierać się w nazwach nadawanych tym roślinom. Wspomniany szczwół w gwarach rosyjskich nosi nazwy вонючал трава, вонючка, вонючник, a jedno z jego polskich mian brzmi bzducha (Encyklopedia zielarstwa, 2000, 542). Mianem вонючал mрава określany jest także вёх sдовитый (Cicuta virosa L.), czyli szalej jadowity (Шутов, 2016), bardziej znany jako cykuta. Ta wyjątkowo toksyczna roślina przypomina pietruszkę (zapewne stąd wzięła się nazwa ludowa кошачья nетрушка), zaś jej łodygi i kłącza, które są szczególnie trujące, mają słodki smak, co dodatkowo zwiększa możliwość zatruć ${ }^{13}$. Rosyjskie nazwy ludowe bielunia dziędzierzawy przekazujące informacje o niemilym zapachu to m.in. дурман вонючиц̆, смердячий дур. Obecność w organach roślinnych substancji o charakterze toksycznym może również objawiać się smakiem - palącym i ostrym (wywołanym

12 Zob. https://www.atlas-roslin.pl/pelna/rosliny-trujace.htm\#TRESC-205 (dostęp: 15.11.2020).

13 Por.: Encyklopedia zielarstwa, 2000, 538; https://www.atlas-roslin.pl/pelna/ gatunki/Cicuta_virosa.htm (dostęp: 15.11.2020). 
przez związki goryczowe), co powoduje, że zwierzęta starają się unikać tego typu roślin. Te specyficzne walory smakowe stały się podstawą nominacyjną niektórych z nazw trujących roślin leczniczych, takich jak rdest ostrogorzki, ros. zopeu, перечный (Polygonum hydropiper L.), w rosyjskim nazewnictwie ludowym znany jakо водяной переи, гречиха перечная, горчак перечный, горчица дикая (лесная), горчичная трава, горчишка. Miana te nawiązują do ostrego, piekącego smaku liści, wywołujących bąble przy żuciu, a także gorzkich owoców, które, przedostając się do zboża, nadają mące gorycz (Mowszowicz, 1972, 28). Rośliną leczniczą i zarazem silnie trującą jest bylica piołun, ros. польюнь горькал (Artemisia absinthium L.) - bylina o trwałym i wyjątkowo gorzkim smaku, którego językowy ślad widoczny jest także w mianach ludowych polskich: paleń, gorzkie ziele oraz rosyjskich: пален, горечь, горечник, горькуша, горчанища. Człon gatunkowy łacińskiej nazwy absinthium ,pochodzi z języka greckiego i oznacza 'gorzki, lecz pożyteczny' (Kozłowski, 2007, 46). Zarówno polska nazwa piołun, jak i rosyjska noлbıłb to wyrazy pochodzenia prasłowiańskiego, najprawdopodobniej wywodzące się od pel- 'palić' i * poléti 'гореть, пыцать' (см. полено, палить) - obydwie interpretacje etymologiczne można powiązać z gorzkim, palącym smakiem łodyg, liści i kwiatów tego gatunku (por.: Brückner, 1970, 414; Фасмер, 1987, 320).

Niektóre z nazw roślin trujących zawierają przestrogę $\mathbf{w}$ postaci odniesienia do śmierci, przy czym także śmierci zwierząt, które niechcący owe rośliny spożyją. Piękny i bardzo toksyczny tojad mocny, ros. борец крепкий (Aconitum firmum Rchb.) nazywany jest piekielnym zielem, wilczym jadem oraz mordownikiem i zbliżonymi określeniami, jak: mordecznik, morderznik, morderz. Rosyjskie gwarowe określenia tej niebezpiecznej rośliny to m.in. wspomniane wcześniej волкогуб, волкобой, a także волчй корень, мышеубийца, мышиная смерть, козья смерть, козабой. Co ciekawe, według antycznych przekazów, poświęconych tak niezawodnej truciźnie, jaką jest tojad, „myszy miały ginąć od samego jego zapachu. Nazywano go zatem 'zabójcą myszy' (myoktonos). Po spożyciu go ginęły także wilki i pantery, skąd z kolei nazwy 'zabójca wilków' (lykoktonos) i 'dusiciel panter' (pardalianchos)” (Siek, Ryś, Sein Anand, 2013, 644). Trujący zimowit jesienny (Colchicum autumnale L.) nosi ludowe miano собачья смерть. O jego toksyczności świadczy polska nazwa gwarowa omieg, odnosząca się także do wspomnianego tojadu mocnego (Waniakowa, 2012, 166). Widłak goździsty (Lycopodium clavatum L.) to w gwarach m.in. babimór i morzybab (Waniakowa, 2012, 110-111). Przekaz dot. jadu, cierpienia znajdujemy także w nazwach ciemiężycy zielonej, ros.

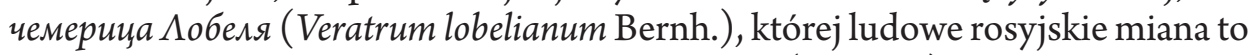
m.in. чемеричный корень, чермис, чемера, чемерка (чемёрка), чемёрник, чемерис. Nazwy te powstały na bazie rdzenia чемеp, który można wyjaśnić jako 'отрава', 'боль' < * с̌еmerъ < kemerъ (Бугаёв, 2010, 303).

Należy zauważyć, że elementy językowe wskazujące na toksyczne właściwości mogą występować także w lacińskiej nomenklaturze botanicznej, w szczególności w nazwach roślin, których okres stosowania w charakterze trucizn 
sięga czasów antycznych lub późniejszych, np. średniowiecza. Pokrzyk wilcza jagoda swoją nazwę rodzajową Atropa (Atropa belladonna L.) „zawdzięcza jednej z mitycznych greckich bogiń losu (Mojr) - Atropos, której zadaniem było przecinanie linii życia, natomiast „belladonna (z wł. 'piękna pani') odnosi się do tego, iż ekstrakt z tej rośliny powodował rozszerzenie źrenic, czyniąc niewieście spojrzenie bardziej atrakcyjnym" (Ciechomska, 2014, 20). Człon gatunkowy nazwy wykorzystywanego od czasów prehistorycznych maku lekarskiego, ros. мaא снотворныци - Papaver somniferum L. wywodzi się od łacińskich słów „somnium - sen, fero - niosę, dosłownie można go przetłumaczyć jako 'niosący sen’” (Serwicka-Kapała, 2004, 190). Etymologia nazwy rodzajowej Papaver jest niepewna - można ją wywieść od łac. „papa, pappa (Аетское слово, обозначающее еду) < рарро 'есть, кушать' (на Аетском языке) і verus 'настоящий' $[. .$.$] ; Аано из-за$ того, что сок мака примешивали в детскую пищу, чтобы дети кучше спали” (Хапаев, Хапаева, 2015, 226). Według innej interpretacji ta nazwa „wiąże się ze starożytnym językiem literackim Indii - sanskrytem, gdzie papaver znaczy 'zgubny sok' lub 'puchnąć'” (Karczmarczuk, 2010, 87-88).

$\mathrm{Z}$ trującymi roślinami leczniczymi o wyjątkowo długiej tradycji stosowania związane są różne legendy i przekazy apotropaiczne, mające swe oparcie w mitologii i kulturze:

Hyoscyamus niger L. (lulek czarny) znany był już w starożytnej Grecji i Rzymie jako roślina powodująca szaleństwo, śmierć, demencję, ale także obdarzająca darem prorokowania, stąd jej antyczne nazwy to pythonion i apollinaris. Datura stramonium L. (bieluń dziędzierzawa), mająca podobne działanie, również łączona była z wyrocznią w Delfach. [...] Kaplanki bogini Hekate znały halucynogenne i nasenne działanie takich roślin, jak Atropa belladonna, Mandragora officinarum L. (mandragora lekarska) czy Scopolia carniolica Jacq. (lulecznica kraińska), a rośliny te łączone były z takimi mitologicznymi postaciami jak Medea czy Kirke, które sporząazały $\mathrm{z}$ nich magiczne mikstury. [...] rośliny, które w starożytności były przypisywane boginiom śmierci (na przykład Hekate), w średniowieczu zaczęły być utożsamiane z diabłem, na przykład przez Hildegardę z Bingen (Ciechomska, 2014, 23).

Łacińskie nazwy rodzajowe trujących i leczniczych zarazem bylic - bylicy piołunu (Artemisia absinthium L.), bylicy pospolitej (Artemisia vulgaris L.) i bylicy bożego drzewka (Artemisia abrotanum L.) wywodzone są od imienia Artemidy będącej stróżem ogrodu zielarskiego Hekate na Kolchidzie (zob. Kawałko, 1986, 65).

Warto nadmienić, że nazwy roślin trujących nie zawsze niosą przekaz nt. szkodliwego działania, ponieważ $w$ trakcie ich nadawania mogły dominować inne motywy, które wywarły wpływ na taką, a nie inną językową formę nazwy. Zawierająca śmiertelnie trujące glikozydy i saponiny, a przy tym wdzięczna i aromatyczna konwalia majowa, ros. мандыш майский (Convallaria maialis L.), w języku rosyjskim ma zaledwie kilka 'ostrzegawczych' nazw 
ludowych - вольи ягоды, волчья фиалка, виноград ядовитый, natomiast jej polskie gwarowe nazwy raczej nie cechują się taką motywacją. O potencjalnym niebezpieczeństwie nie informują nazwy silnie trujących roślin leczniczych, obdarzonych przy tym pięknymi kwiatami, takich jak naparstnica purpurowa, ros. наперстянка пурпурная (Digitalis purpurea L.), czy miłek wiosenny, ros. адонис весенний (Adonis vernalis L. ${ }^{14}$. Także rośliny trujące powszechnie występujące w stanie dzikim na terenie Polski i Rosji, jakimi są wrotycz pospolity, ros. пижма обыкновенная (Tanacetum vulgare L.) i glistnik jaskółcze ziele, ros. чистотел большой (Chelidonium majus L.), pośród swoich licznych nazw gwarowych nie mają takich, które wskazywałyby na to, że zawierają one związki chemiczne niebezpieczne dla ludzi.

W podsumowaniu tej krótkiej analizy należy podkreślić, że trujące właściwości roślin dość często znajdują swoje odbicie w ich nazewnictwie, przy czym zarówno botanicznym, jak i ludowym. Jak się wydaje, miana ludowe są bardziej ekspresywne i obrazowe niż oficjalna nomenklatura. Wynika to z faktu, że czynnik pragmatyczny dotyczący zastosowania roślin użytkowych jest dość popularny w mianownictwie ludowym, które ponadto nierzadko jest nacechowane stylistycznie. Informacje o toksyczności roślin leczniczych zawarte w ich nazwach mają bardzo duże znaczenie dla użytkowników języka, gdyż mogą stanowić cenną wskazówkę w zakresie ich (nie)stosowania, a dzięki temu zmniejszyć ryzyko potencjalnego zatrucia - pod warunkiem znajomości nazw i właściwej identyfikacji trującego gatunku.

\section{Bibliografia}

Atlas roślin naczyniowych Polski. http://www.atlas-roslin.pl/ (dostęp: 15.11.2020).

Bobrowicz, G. Stownik Polskiego Języka Przyrodniczego. http://bobrowicz.eu/pl/slownik-przyrodniczy/ (dostęp: 15.11.2020).

Bohne, B., Dietze, P. (2008). Rośliny trujące: 170 gatunków roślin ozdobnych i dziko rosnacych. Warszawa: Bellona.

Brückner, A. (1970). Stownik etymologiczny języka polskiego. Warszawa: Wiedza Powszechna.

Chodurska, H. (2003). Ze studiów nad fitonimami rękopiśmiennych zielników wschodniosłowiańskich XVII-XVIII wieku. Kraków: Wyd. Naukowe Akademii Pedagogicznej.

${ }^{14}$ Ludowe miana naparstnicy purpurowej w jęz. polskim i rosyjskim motywowane są głównie kształtem kwiatów: dzbanuszek, naparstnik, palecznik, paluszniczek (Waniakowa, 2012); наперстяночная (наперсточная) трава, наперсник, рюмочник, месной колокольчик. Obecne w gwarach określenia miłka wiosennego mają różne podstawy onomazjologiczne, lecz żadna z nich nie wskazuje na toksyczność tej rośliny: gorzykwiat, gorzekwiat, kochanek, wole oko, zawilec (Bobrowicz online), аппетитная (запальная, черная) трава, волосатик, заячий мак, сосонка, черногорка (Plantarium online). 
Ciechomska, M. (2014). Maści czarownic, śmiertelne trucizny i serum prawdy: Historia $i$ wykorzystywanie psychoaktywnych roślin z rodziny Solanaceae, Zeszyty Naukowe Towarzystwa Doktorantów UJ - Nauki Ścisłe, 9 (2), 19-34.

Doroszewski, W. (1982). Język, myślenie, działanie: rozważania językoznawcy. Warszawa: PWN.

Gawryś, W. (2008). Stownik roślin zielnych: łacińsko-polski. Kraków: Officina Botanica. Karczmarczuk, R. (2010). Mak - piękny i niebezpieczny. Wszechświat, 111, 87-92.

Kawałko, M.J. (1986). Historie ziołowe. Lublin: KAW.

Kopaliński, W. (1985). Stownik mitów i tradycji kultury. Warszawa: PIW - Drukarnia Naukowo-Techniczna.

Kozłowski, J.A. et al. (2007). Zioła z apteki natury. Poznań: Publicat SA.

Kuźnicka, B. (1992). Znaczenie roślin halucynogennych $w$ polskich tradycjach kulturowych. Zarys problematyki, Analecta. Studia i Materiały z Dziejów Nauki, 1, 111-122.

Mirek, Z., Piękoś-Mirkowa, H., Zając, A., Zając M. et al. (2002). Flowering plants and pteridophytes of Poland a checklist $=$ Krytyczna lista roślin naczyniowych Polski. Kraków: W. Szafer Institute of Botany, Polish Academy of Sciences.

Mowszowicz, J. (1972). Rośliny trujące. Warszawa: WSiP.

Mowszowicz, J. (1982). Przewodnik do oznaczania krajowych roślin trujących i szkodliwych. Warszawa: PWRiL.

Noszczyk, W. (red.) (2016). Dzieje medycyny w Polsce. T. 1. Warszawa: PZWL.

Olesińska, K., Sugier, D., Luchowska, K. (2016). Znaczenie gospodarcze roślin leczniczych. W: Rośliny w medycynie, farmacji i przemyśle (17-32). M. Maciąg, M. Szklarczyk (red.). Lublin: Wyd. Naukowe TYGIEL sp. z o.o.

Rejewski, M. (2016). Nazwy roślin. Toruń: Wyd. Naukowe UMK.

Rumińska, A., Ożarowski, A. (red.) (1990). Leksykon roślin leczniczych. Warszawa: PWRiL.

Serwicka-Kapała, A. (2004). Obraz świata w tacińskich nazwach roślin leczniczych. Linguodidactica, VIII, 187-192.

Siek, B., Ryś, A., Sein Anand, J. (2013). Najbardziej popularne trucizny świata grecko-rzymskiego. Przegląd Lekarski, 70, 643-646.

Stec, W. (2016). Metafora w nazewnictwie roślinnym: polskie i rosyjskie nazwy roślin leczniczych motywowane nazwami ze świata zwierzat. Acta Polono-Ruthenica, 21, 99-115.

Strzelecka, H., Kowalski, J. (red.) (2000). Encyklopedia zielarstwa i ziołolecznictwa. Warszawa: Wyd. Naukowe PWN.

Szcześniak, K. (2008). Świat roślin światem ludzi na pograniczu wschodniej i zachodniej Słowiańszczyzny. Gdańsk: Wyd. Uniwersytetu Gdańskiego.

Waniakowa, J. (2012). Polskie gwarowe nazwy dziko rosnacych roślin zielnych na tle stowiańskim. Zagadnienia ogólne. Kraków: Wyd. Uniwersytetu Jagiellońskiego.

Болотина, А. (2007). Словарь лекарственных растений (латинский, английский, немецкий, русский). Москва: Руссо.

Бугаёв, И.В. (2010). Научные и народные названия растений и грибов. Томск: ТМАПресс.

Колосова, В.Б. (2011). Этноботанические заметки. V. Аконит. Славяноведение, 4, 65-74.

Аавренова, Г.В., Аавренов, В.К. (1997). Энииклопедия лекарственных растений. Т. 1. Аонецк: Аонеччина. 
Аагерь, А.А. (2002). Травник сибирского иелителя. Москва: Рипол классик.

Плантариум: открытьй онлайн атлас-определитель растений и лишайников России и сопредельных стран. 2007-2020. http://www.plantarium.ru/ (dostęp: 15.11.2020).

Сельскохозяйственный энииклопедический словарь (реА. комлегия) (1989). Москва: Советская энцикиопедия.

Стец, В. (2011). Особенности номинации ядовитьх лекарственных растений в русском и польском языках. W: Русский язык и литература: Проблемь изучения и преподавания в школе и вузе. Сборник научных работ (163-167). А.А. Куарявцева (red.). Киев: КНУ им. Т. Шевченко.

Толковый словарь Ожегова онлайн. https://slovarozhegova.ru/ozhegov.php (dostęp: 15.11.2020)

Фасмер, М. (1987). Этимологический словарь русского языка, Т. 3. О.Н. Трубачёва, (пер. с нем. и доп.) Москва: Прогресс.

Хапаев, Б.А., Хапаева, А.Б. (2015). Этимологический словарь названий лекарственных растений (с карачаево-балкарскими фитонимами). Черкесск: БИЦ СевКавГГТА.

Шапошников, А.К. (2010). Этимологический словарь современного русского языка, Т. 1. Москва: ФАинта, Наука.

Шутов, В.В. (2016). Словарь народных названий растений. Москва: ИзАательские решения. 